\title{
Between Emergency Responses and Rights-based Approaches: Addressing Poverty and Undernutrition in Eastern India
}

\author{
Arjan de Haan, Amaresh Dubey and Gita Sabharwal'
}

\begin{abstract}
This article analyses poverty and undernutrition in two of India's poorest states - Orissa and West Bengal. We describe poverty and undernutrition in these two states, focusing on within-state differences. We argue that the persistence of the differences within Orissa is due to 'structural inequalities' in the access to and delivery of central government programmes. We then explore the preliminary evidence on West Bengal's recent efforts to improve service delivery through a programme of decentralisation. The conclusion reflects on the nature of approaches that are needed to ensure programmes work even in the most remote and deprived places.
\end{abstract}

\section{Poverty and calorie inequalities within Orissa and West Bengal}

There appears to be a paradox between the headline messages on inequality and the reality of India's lagging areas. While at a national level the Gini coefficient is relatively low and has continued to be around $0.32-0.33$ over the last two decades (during which China's has increased from 0.29 to 0.46 ), gaps are visibly widening between rural and urban areas, across India's states, and within states. Drèze and Srinivasan (1996) and Dubey and Gangopadhyay (1998) were among the first to highlight the high and increasing divergence below state-level using the level of 'NSS regions' which presents stark pictures about Orissa's three and West Bengal's four main regions. Recently, one of the authors of this article also has been engaged in presenting a picture of poverty at the even lower district level (Bhandari and Dubey 2009). While this level of disaggregation remains technically challenging, we believe it to be critically important as the country's decentralisation process increasingly looks to give responsibilities over to the hand of lower levels of government.

Table 1 presents the poverty and calorie results of the analysis of the 2004-05 NSS sample compared with the 1993-4 data.

It is clear that poverty rates and mean calorie consumption data show great variation within states both in terms of geographic region and in terms of rural and urban breakdowns. Most worryingly, the differences are stubborn and in many cases widening. For West Bengal, the range of poverty rates from highest to lowest has declined somewhat across regions and between rural/urban areas from 1993 to 2005 . But disparities in poverty rates within Orissa as measured by range - particularly in rural areas have exploded over this time. For mean calorie consumption, the range of levels within both states - by region and by rural and urban area has increased dramatically across the board.

Given these variations, we argue that not enough attention is being paid to finding out what determines the differences within these states, and what the implications of these are for nutritional and anti-poverty strategies. The next two sections look at the determinants of the high levels of deprivation and disparities that exist within the two states, and experiences with 
conditions under which government services can be made to work or improve.

\section{The KBK phenomenon and political economy of emergency responses in Orissa}

The KBK region (Kalahandi-Bolangir-Koraput) of Orissa has for decades illustrated India's worst development problems, once again highlighted in the most recent NSS data, and perennially appearing in the newspapers because of the extreme cases of starvation deaths. The Orissa state government's policies for the non-coastal parts of Orissa are marked by a great deal of neglect - even though programmes for the KBK region have existed for decades, many 'centrallysponsored', and with Prime Ministerial attention. The area is seen as remote and inhabited by tribal peoples. Reports of malnutrition and even starvation are typically denied at first, reactions are slow, and often prompted by central government institutions rather than driven by motivations within the state government. Incidences of violence are seldom satisfactorily addressed or even investigated by the state government. Beyond the neglect, the responses are marked by an emergency mode: rather than addressing the root causes of the problems, discussed below, the response is to provide relief, drawing on centrally-available resources (Jayal 1999).

The relation between the coastal and 'remote' Orissa regions is marked by deep political and overlapping social inequalities. Orissa as a political unit has a very short history (the movement for a separate western Orissa state, Koshal, has remained weak). Orissa's political elite - coastal, higher caste - has continued to have a very small economic and social base (Mohanty 1990), with limited impact of land reforms, without the class transformations that have happened in Andhra Pradesh for example, and certainly not the social churning that Bihar has witnessed. By and large, the interests of remote areas and deprived groups remain underrepresented on the political scene.

Discrimination vis-à-vis lower castes and tribes is deeply rooted, and the administrative programmes and the categories it has employed have not addressed attitudes of discrimination (de Haan 2007).

Historically, the integration of Orissa has been perceived and described as a process of 
colonisation, rather than development (Bailey 1957). Despite legislation, security of access to land remains limited, and encroachment common. Displacement has affected large numbers of poor people, and resettlement programmes have been poorly implemented (much-criticised donor-supported programmes tend to have the better conditions). Many Adivasi families depend on forests, but deforestation, exploitative state control over forests, privatisation and the weak role of local government relating to non-timber forest products have reduced livelihood opportunities (Saxena 2003; Pattnaik 2006), which is likely to have been a central reason for the lack of improvement in nutrition indicators particularly in those areas.

The role of local governance in access to natural resources is an example of the broader problem of decentralisation in Orissa. ${ }^{1}$ Legislation for decentralisation in Orissa has been progressive, for example through the introduction of a fourth layer of local governance (relevant because of the dispersion of population in the state). But socioeconomic inequalities appear to reproduce political inequalities negatively affecting the potential that local governments will effectively implement programmes (PRAXIS 2002).

Finally, in assessing the effectiveness and the role of local governance it is important to assess the role of civil society and social mobilisation. Despite a number of very strong NGOs in Orissa, its reputation has been damaged - for various reasons including allegation of corruption and its commercialisation after the cyclone - and collaboration with government has remained weak in general (thus limiting its role in programme implementation). More critically, as already indicated, and with the significant exception of protests against developmentinduced displacement, social mobilisation and articulation of voice among the large numbers of deprived groups have remained limited, thus limiting bottom-up processes that could strengthen accountability.

The history of poverty responses in Orissa thus illustrates a worst case, an area where multidimensional forms of exclusion have kept large groups in deep poverty and malnourished for long periods of time, despite existence of extensive policy frameworks. The predominant emergency mode of response has not worked, and has enabled policy makers to avoid addressing deeply-rooted forms of exclusion. For poverty and nutrition policies to be effective there is an urgent need to strengthen accountability.

\section{Improving service delivery: strengthening local governance in West Bengal}

West Bengal's socioeconomic history is radically different from Orissa. It has performed better than Orissa in poverty reduction as latest NSS data in Table 1 indicate, though perhaps less well than expected given its political leaders' demonstrated commitment to rural development and equity. In this section, we discuss one of the recent efforts to strengthen and enhance the effectiveness of programmes to reduce poverty by strengthening local governance and rural decentralisation. We argue that it can be seen as a test case of the importance of local participation for improving service delivery, although we have doubts about its relevance for an extreme context such as Orissa. ${ }^{2}$

West Bengal's government has recently committed itself to strengthening decentralisation, but prior to that the political ideology of the Left Front served as the driver of decentralisation. Strengthening local governments has been a tool for sharing power and a means for the party to reach out to the rural masses. Decentralisation is seen as the foundation for equitable development, taking administration close to people and addressing rural poverty and improving the delivery of services for all.

Recent initiatives emphasise participatory or bottom up planning, and intensive hamlet level mobilisation and annual planning across the 12 poorest districts of the state. The government is progressively devolving finances and functions to Panchayats, with departments directly transferring money to Panchayats, with, for example, health workers reporting to them. The state ranks among the top of the league on the devolution index for the country, where Orissa is among the worst performers.

Savings and credit groups or self-help groups (SHGs) at the hamlet level form the bedrock for women's participation in panchayat activities. Over two-thirds of women are members of SHGs and typically participate in hamlet level panchayat 
meetings. The SHGs have served as a key to the economic and political empowerment of women and is translating into 'voice and influence' in the allocation of private and public goods.

The government has set up a comprehensive capacity building plan for elected representatives and the panchayat officials, to build capacities of the leaders of all tiers to manage resources, collect revenues and accounting, plan and deliver services. Premier academic institutions like IIM

Kolkata have been used to train elected Panchayat heads, and support gram panchayats through a network of mobile trainers and the use of district and extension training centres.

The institutionalised mechanisms to increase participation of citizens in developing and implementing plans and improving transparency and accountability in the functioning of Panchayats appear to be working. Hamlet level meetings are a regular feature of Panchayats in West Bengal, which decide for example on allocation of budgets for public investments including the various poverty reduction programmes. Participation levels are typically high for all social groups, including women.

To deepen transparency in service provisioning and administration, the government has legislated to promote disclosure norms by all Panchayats (and organise social audits from 2009 onwards). It has made it mandatory to display the budget, names of beneficiaries for all poverty reduction programmes, and the public investments planned for the year. All households also receive the annual report of the gram panchayat including income and expenditure statements.

The combination of efforts - community mobilisation, transparency mechanisms, capacity building of officials and elected representatives, and enhanced financial devolution - is having positive impacts.

According to the evaluation (Sambodhi forthcoming) and other studies: ${ }^{4}$

Over 90 per cent of the GP plans reflect hamlet level priorities with the majority of the development expenditure targeted at the poor, specifically the SC and ST (data on effectiveness of targeting to social groups will soon be available).
Three out of four households participate regularly in panchayat meetings with one-third claiming to influence decision-making. Significantly, according to the evaluation, officials were in post, which allows citizens to hold them to account. The system of disclosure is operating effectively.

- Decentralisation has resulted in improvement in access and delivery of basic services specifically for drinking water, primary healthcare, education and toilets. ${ }^{5}$ Eight out of ten households perceive an improvement in the delivery of basic services, including all centrally sponsored schemes across project villages. These improvements will be further corroborated by the independent citizen's report card which is due soon. ${ }^{6}$

- Efficient functioning of panchayats is also contributing to increased income and assets for 70 per cent of poor households. Just under half of these households demonstrate a growth of 15-30 per cent in their average household income. More than 35 per cent of the households indicate significant or highly significant increase in livelihood assets, which they are using to diversify economic activities, including livestock, trading and small business opportunities. The project has also provided financial services to the poor, through the improved network of SHGs.

- Finally, the impact evaluation indicates a significant increase in revenue generation by panchayats, mainly through non-tax revenues like rental income, trade licences and user charges. The capacity building is also resulting in Panchayats effectively leveraging and using more resources through the Centrally-Sponsored Schemes (Shyam 2008), and in increasing community contributions.

Decentralisation seems essential in the delivery of India's development programmes, but this is not enough. The West Bengal experience indicates that it needs to go hand in hand with capacity building of elected representatives and officials and community mobilisation. Equally important are the investments to enhance the efficiency of panchayats specifically to manage its resources and plan effectively for the future.

\section{Conclusion}

The key concern of this article is the high level of disparity within Indian states both from poverty and food consumption perspectives and as a 
reflection of disparities in voice and accountability. The marked differences between states are well known (Harriss 1999). Here we are particularly concerned with the differences within states, and particularly the institutional and policy conditions that determine the different performance of development programmes.

A particular concern is that programmes seem to work least well where they are most needed. Orissa illustrates this case and highlights that poverty and undernutrition are part of a much broader development failure, rooted in deep social and political inequalities. It is unlikely that successful experiences from elsewhere can be transplanted straightforwardly - or even at all to these most deprived areas.

The West Bengal experience is equally unique. It has a long history of political mobilisation, which arguably makes new initiatives more likely to succeed than in Orissa. West Bengal too has

\section{Notes}

* The views expressed in this article do not necessarily represent those of DFID.

1 See Rajaraman and Sinha (2007a) on a comparison of functional devolution in four of India's poorest states. Rural decentralisation follows Constitutional provisions at the national level. The 73rd Constitutional Amendment Act, enacted by the national Parliament, supports state governments to empower PRIs and to strengthen the participation of women and other weaker sections in panchayats.

2 The programme includes monitoring at least two points, and the first report is now available - the rest of this section relies mainly on this (Sambodhi 2009 and Sambodhi forthcoming; De 2009).

\section{References}

Bailey, F.G. (1957) Caste and the Economic Frontier. A Village in Highland Orissa, Manchester:

Manchester University Press

Bhandari, Lavees and Dubey, Amaresh (2009)

'District Level Poverty Estimates in 2004-05', mimeo, New Delhi: Indicus Analytics

De, Indranil (2009), 'Can Decentralisation Improve Rural Water Supply Services?', Economic and Political Weekly, 3 January remained remarkably poor, and with large inequalities too, of a different nature, but equally deep-rooted. But the experience with the decentralisation programme is encouraging. Decentralisation provisions have been the same across all Indian states, but they appear to have had little impact in Orissa.

In West Bengal, while it is still early days, the evidence on the capacity building of local officials combined with social mobilisation, around specific service delivery issues, indicates that conditions can be created under which development programmes can be made to work better. For Orissa, more analysis and experimentation is necessary for solutions to emerge to reduce the disparities within the state. Such solutions have to come from within the state itself, and success of externally-driven efforts and programmes will depend on strengthened local capacity, commitment and accountability.

3 Ministry of Panchayati Raj 2008. According to a Ministry Press Note of 2 March 2009, West Bengal came 2nd in a National ranking of effective devolution, while Orissa came 18th (slightly better than Bihar).

4 De 2009; Govinda Rao and Vasanth Rao 2008; Srinivasan et al. 2007; Rajaraman and Sinha 2007a, 2007b.

5 The impact evaluation indicates that 3 per cent to 5 per cent more households access these services in project gram panchayats as compared to control villages.

6 Under NREGA over 90 per cent of the poor have been employed, which is 20 per cent more as compared with the control villages. Similarly, more numbers of out of school children end up enrolling and completing primary education across these panchayats.

de Haan, A. (2007) 'Labelling Works: The Language and Politics of Caste and Tribe in India', in R. Eyben and J. Moncrieffe (eds), The Power of Labelling. How People Are Categorized and Why it Matters, London: Earthscan: 143-59

Drèze, J. and Srinivasan, P.V. (1996) Poverty in India: Regional Estimates, 1987-1988, DEP No. 70, London: London School of Economics

Dubey, A. and Gangopadhyay, S. (1998) 'Counting the Poor: Where are the Poor in 
India?', Sarvekshana: Analytical Report 1, February

Govinda Rao, M. and Vasanth Rao U.A. (2008) 'Expanding the Resource Base of Panchayats: Augmenting Own Revenues', Economic and Political Weekly, 26 January

Harriss, J. (1999) 'Comparing Political Regimes across Indian States. A Preliminary Essay', Economic and Political Weekly, 27 November

Jayal, N.G. (1999) Democracy and the State. Welfare, Secularism and Development in Contemporary India, Delhi: Oxford University Press

Ministry of Panchayati Raj (2009) Press Note.

Panchayat Empowerment and Accountability

Incentive Scheme (PEAIS) - Assessment of the States for 2008-09, 2 March, New Delhi

Ministry of Panchayati Raj (2008) State of Panchayats 2007-08, Government of India, www.panchayat.nic.in/viewContentItem.do?Vi $\mathrm{ew}=$ viewItem\&itemid $=4370 \& p t$ tid $=3672 \&$ fo lderid =3687 (accessed 15 May 2009)

Mohanty, M. (1990) 'Class, Caste and Dominance in a Backward State: Orissa', in F. Frankel and M.S.A. Rao (eds), Dominance and State Power in Modern India: Decline of a Social Order, Delhi: Oxford University Press: 321-67

Pattnaik, M. (2006) Strategy for Non Timber Forest Produce Based Livelihood Interventions, www.worlp.com/images/publication/ WORKING\%20PAPER\%2058.pdf (accessed 15 May 2009)

PRAXIS (2002) The Accountable State, report prepared for Government of Orissa, Orissa
Rajaraman, I. and Sinha, Darshy (2007a) 'Functional Devolution to Rural Local Bodies in Four States', Economic and Political Weekly, 16 June

Rajaraman, Indira and Sinha, Darshy (2007b) Tracking Functional Devolution By States To Panchayats, Working Paper National Institute of Public Finance and Policy, New Delhi, www.nipfp.org.in/working_paper/ wp_2007_48.pdf (accessed 15 May 2009)

Sambodhi (forthcoming) Poverty Impact Assessment of Critical Support for Poverty Redcution, Panchayat and Rural Development Department, West Bengal

Sambodhi (2009) Poverty Impact Assessment of Critical Support for Poverty Reduction, Panchayat and Rural Development Department, Government of West Bengal http://wbdemo5.nic.in/html/asp/ news_select 1.asp (accessed 15 May 2009) Saxena (2003) Livelihood Diversification and NonTimber Forest Products in Orissa: Wider Lessons on the Scope for Policy Change?, ODI Working Paper 223, London: Overseas Development Institute Shyam, Ashtekar (2008) 'The National Rural Health Mission: A Stocktaking', Economic and Political Weekly, 13 September

Srinivasan, K.; Shekhar, C. and Arokiasamy, P. (2007) 'Reviewing Reproductive and Child Health Programmes in India', Economic and Political Weekly, 14 July 